\title{
Response of snap bean to biogas slurry combined with either rock Phosphate or super phosphate fertilizers
}

\author{
M. Y. Abou-Zeid and El-Sayeda H. M. El-Badawy and A. El. Sherif \\ Soils, Water and Environ. Res. Inst. A.R.C., Giza, Egypt.
}

\begin{abstract}
This research was carried out to study the potential use of by-products of biogas production, i.e. biogas slurry (BS) generated from cattle dung, as nutrient sources in agriculture. The pot trials were conducted under green house conditions on the growth, yield of snap bean and their chemical composition. Some soil enzymes, i.e, nitrogenase and dehydrogenase were determined, also available P. Snap bean was fertilized with various sources

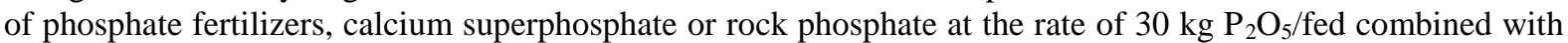
BS.

Results showed that vegetative growth parameters significantly increased by using BS and RP or SP for two used varieties, applying of $10 \mathrm{~m}^{3} \mathrm{BS}+30 \mathrm{~kg} \mathrm{P}_{2} \mathrm{O}_{5} / \mathrm{fed}$ as SP gave the maximum values of vegetative growth parameters for Paulista variety. For other variety, Xera, $10 \mathrm{~m}^{3} \mathrm{BS}+30 \mathrm{~kg} \mathrm{P}_{2} \mathrm{O}_{5} / \mathrm{fed}$ as SP led to the highest plant height. While $2.5 \mathrm{~m}^{3} \mathrm{BS}+30 \mathrm{~kg} \mathrm{P}_{2} \mathrm{O}_{5} /$ fed as RP gave the highest values of plant dry weight and No of branches. With respect to yield and its components, pods weight/plant and pod length of Xera cultivar significantly increased over control, also pods weight /plant for another cultivar significantly increased over control as a result of using BS and various sources of $\mathrm{P}$ fertilizer

Regarding the leaves chemical composition, using Bs combined with RP or SP caused significant increase of $\mathrm{N}, \mathrm{P}, \mathrm{K}$ as macronutrients, where $10 \mathrm{~m}^{3} \mathrm{BS}+30 \mathrm{~kg} \mathrm{P}_{2} \mathrm{O}_{5} / \mathrm{fed}$ as $\mathrm{RP}$ gave its highest values for two used varieties. Micronutrients Fe, Mn, Zn and Cu significantly increased over control. Applying of rock phosphate (RP) with BS was more effective on most of these nutrients than super phosphate (SP) + BS for the two cultivars used.

For the pod chemical composition which significantly increased, N,.K and total protein of Xera variety reached to the maximum values by using $\mathrm{SP}+10 \mathrm{~m}^{3} \mathrm{BS}$. While the highest value of T.P\% obtained by RP $+10 \mathrm{~m}^{3} \mathrm{BS}$. Fe, $\mathrm{Mn}$ and $\mathrm{Zn}$ concentration (ppm) enhanced by using RP $+10 \mathrm{~m}^{3} \mathrm{BS}$. For Paulista cultivar, T.N, T. protein and Fe increased up to the greatest values by $\mathrm{RP}+10 \mathrm{~m}^{3} \mathrm{BS}$, while T.P and $\mathrm{Mn}$ reached to the maximum values by using $\mathrm{SP}+10 \mathrm{~m}^{3} \mathrm{BS}$.

With regard to biological activity and available phosphorus, data showed significant increases by the treatment under this study. Clearly applying RP along with $10 \mathrm{~m}^{3} \mathrm{BS}$ gave the highest values of dehydrogenase, nitrogenase enzyme activity and total count of bacterial more than those obtained by $\mathrm{SP}+10 \mathrm{~m}^{3} \mathrm{BS}$, while the best results for available $\mathrm{P}$ were obtained by $\mathrm{SP}+10 \mathrm{~m}^{3} \mathrm{BS}$. Accordingly, this study ensured that the use of rock phosphate with biogas slurry may be recommended as a substitute for super phosphate with biogas slurry in snap bean production.
\end{abstract}

Key words: biogas slurry, rock phosphate, super phosphate, nitrogenase enzyme, dehydrogenase enzyme, snap

\section{Introduction} bean, $\mathrm{N}, \mathrm{P}, \mathrm{K}, \mathrm{Fe}, \mathrm{Mn}, \mathrm{Zn}, \mathrm{Cu}$.

Snap bean is one of important vegetable in Egypt, which has a great weight for both local consumption and export. Egyptian Ministry of Agriculture aimed to extend the cultivation area of snap bean especially in newly reclaimed land because of its economic value. Snap bean is the second exportable vegetable in Egypt.

Lack of adequate nutrient supply and poor soil structure are the main constraints to agricultural production systems in low-input agriculture. Chemical fertilizers are not the most appropriate solution to overcome the seconstraints because use of chemical fertilizers is expensive and a threat to human health and the environment Weltzein (1990)]. Integration of organic with inorganic fertilizers improves the physiological system of the crop, provides adequate growth regulating substances and modifies soil physico-chemical behavior and results in augmented crop yield (Hukkeri et al, 1977). Hence, it is suggested that there should be an emphasis on finding alternatives to chemical fertilizers suchas biogas slurry, compost which are cheaper than other sources of nutrients and relatively safe. Nutrients can be added to the soil through inorganic fertilizers or organic input including biogas slurry, farm yard manure (FYM), animal waste and crop residues. Biogas slurry is a by-product obtains from the biogas plant after the digestion of dung or other biomass for generation of methane rich gas. Biogas slurry supplies essential nutrients enhance water holding capacity, soil aeration, accelerates root growth and inhibit weed seed germination. It contains appreciable amounts of organic matter (20 to $30 \%$ ). Cattle dung, crop residues and other aquatic biomass are available in large amounts in many of the developing countries. It can be used in liquid, compost, and dry form and is a very good fertilizer/composting substance for agricultural crops. It is a more easily available form of compost than traditional compost (Gurung1998). Regarding increased yields, Gurung1998 stated that the most 
responsive crops to bio slurry and bio slurry compost are vegetables; root crops, potatoes, fruit trees, maize, and rice. Furthermore, bio slurry has the potential not only to improve soil fertility and soil structure, but also to act as a plague repellent. Finally, seeds treated with bio slurry have given better germination rates. Application of digested bio slurry increases the crop yield, quality of vegetables like size and shapes. It also helps in reduction of dependence on mineral fertilizer (Karki, 1996). Yield increase due to bio-slurry application has been reported in many crops. Vegetable crops produced with bio-slurry have better quality as compared to those produced with chemical fertilizer (Krishna, 2001).

Biogas is an important component for energy production from renewable resources (Møller et al., 2009) and for this reason biogas slurry, the secondary product of the anaerobic digestion process, is increasingly abundant and used as a fertilizer (Moller, 2009). To investigate the effects of biogas and raw slurry on Italian ryegrass yield, $\mathrm{N}$ uptake (two harvests), soil microbial biomass, soil fungi, and rootcolonizing microorganisms, Wentzel and Joergensen (2016) found that Biogas slurries increased the mean total above-ground plant biomass by $66 \%$ and raw slurries by $35 \%$ in comparison to the control. The mean plant $\mathrm{N}$-uptake increased under biogas and raw slurry application by $166 \%$ and $65 \%$, respectively, compared with the unfertilized pots.

Various trials have compared the yields from inorganic fertilizer, organic fertilizers and or combination of both. In many cases, combination of organic and inorganic fertilizers have produced higher yields (Sajjad and Shad, 2014), also Zebider (2011) stated that there is a need to apply both organic and inorganic fertilizers in a balanced way to get expected output or the crop yield.

Compost and bio slurry improves the physical, chemical and biological quality of soil besides providing both macro and micro nutrients to crops. The improvement in qualities include improvement in soil structure, water holding capacity, electrical conductivity, bulk density, lesser soil erosion, preventing the leaching of nutrients and provide nutrients to soil micro flora (Fentaw, 2010). Bioslurry, the residual manure generated through anaerobic decomposition of various organic materials is considered a quality organic fertilizer. About 25 to $30 \%$ of organic matter is converted into biogas during the anaerobic fermentation process, while the rest becomes available as manure (bio-slurry). This residual manure is normally rich in macro and micro nutrients (Islam, 2006; Thu, 2007). Yield responses of vegetable crops to bio-slurry manure application have been reported in different crops including okra (Shahbaz, 2011) maize and cabbage (Karki, 2001). Garg et al., 2005 reported that fertilization of soil with biogas slurry generated from cattle dung improved the yield of wheat over non-modified controls. Grain yield increased with the application of biogas residue, which was attributed to the lower bulk density of soil, increased hydraulic conductivity, and greater moisture retention. Consequently, the improved status of nutrients through amendment of the physical properties of soil contributed to the higher yield of wheat.

Phosphorus $(\mathrm{P})$ is the second important key plant nutrient which affects the overall growth of plants by influencing the key metabolic processes such as cell division and development, energy transport (ATP, ADP), signal transduction, macromolecular biosynthesis, photosynthesis and respiration (Shenoy and Kalagudi, 2005; Khan et al., 2009, 2014). Soils contain very little total P $(0.02-0.5 \% \quad(\mathrm{w}=\mathrm{w})$; Fernandez et al., 2007), of which only $0.1 \%$ is available to plants (Zou et al., 1992). Thus, P needs to be applied to soils as soluble P fertilizers; a small part (1\%) is utilized by plants and the remainder (_99\%) is rapidly converted into insoluble complexes (Mehta et al., 2014). Hence, the recovery efficiency of $P$ is not more than $20 \%$ of applied P in the world soils (Qureshi et al., 2012). Considering the low recovery of applied and native $\mathrm{P}$ and the high cost of chemical phosphatic fertilizers in addition to an increasing concern about environmental degradation (Aziz et al., 2006; Khan et al., 2014), it is important to find viable solutions to increase $\mathrm{P}$ fertilizer use efficiency. Two management options can be effective: (i) increasing the recovery and solubility of applied $\mathrm{P}$ fertilizers and (ii) replacing the expensive chemical P fertilizers with novel, cheaper, more ecologically friendly but nevertheless efficient $\mathrm{P}$ sources, such as indigenous rock phosphates (RPs). The application of RPs directly to the soils has yielded some positive results in acidic soils, but the efficacy of such material is almost negligible in neutral and alkaline soils (Begum et al., 2004). Therefore, efforts have been made to find suitable ways to improve the solubility and efficiency of indigenous RPs. Numerous studies have been conducted to evaluate the efficiency of different amendments to increase the availability and solubility of $\mathrm{P}$ from native and applied sources including RP. Among these, organic amendments, including animal manure, plant residues and green manure (Alloush, 2003; Toor, 2009; Aria et al., 2010; Adesanwo et al., 2012), composts (Nishanth and Biswas, 2008; Wickramatilake et al., 2010; Saleem et al., 2013), and bacterial inoculation (Panhwar et al., 2011; Gupta et al., 2011) are considered beneficial for improving the $\mathrm{P}$ efficiency. In addition, the combined application of water-soluble $\mathrm{P}$ fertilizers with RP is another option to increase the efficiency of RP.

Soil microorganisms have generally been found effective in making $\mathrm{P}$ available to the plants from both inorganic and organic sources by solubilizing and mineralizing complex P compounds (Khan et al., 2014). Similarly, the application of organic manure with phosphate fertilizers is considered another possible means of mobilizing $P$ because of the acidic environment generated during the decomposition of 
the manure (Nishanth and Biswas, 2008). The different types of organic manure increase the microorganisms, release acids in the root rhizosphere and may help to solubilize $\mathrm{P}$ and to increase $\mathrm{P}$ availability to the plants (Hu et al., 2006).

Keeping in view the considerable expense involved in importing raw material for manufacturing $\mathrm{P}$ fertilizers or in $\mathrm{P}$ fertilizers directly imported, it is imperative to explore the possibility of the utilization of indigenous RPs and the ways to increase the efficiency of other P fertilizers. The effects of biogas slurry (BS) on the efficiency of both soluble and insoluble P fertilizers with regard to plant growth and yield have been studied. However, the effect of these combinations on $P$ release capacity (mineralization) of both soluble and insoluble P sources, especially RPs, has been given little attention. Therefore, the present study was conducted to examine the effect of biogas slurry (BS) with soluble $\mathrm{P}$ fertilizers (SP) and insoluble rock phosphate (RP) on $\mathrm{P}$ availability and their subsequent effect on the growth, yields, chemical composition of leaves and pods, also on biological activity of snap bean (Pharsalus vulgaris L.) grown in a greenhouse condition.

\section{Materials and Methods \\ I-Materials:}

\subsection{Seeds:}

Snap bean (Phaseolus vulgaris L.) varieties Xera and Paulista were kindly provided from Horticulture Research Institute, Agriculture Research Center (ARC), Giza, Egypt.

\subsection{Soil:}

A clay soil sample was collected from Moshtohor, Kalubia, Egypt. The soil was slightly alkaline. Soil was then air dried, pulverized and sieved to $2 \mathrm{~mm}$ diameter size to be prepared for snap bean. Some physical and chemical properties of the experimental soil are shown in Table (1) Mechanical and physical analyses were estimated according to Jackson (1973).

\subsection{Biogas slurry and rock phosphate:}

Chemical analysis of the rock phosphate (Table 2) and biogas slurry was estimated according to Black et al., (1982).Chemical analysis of biogas slurry showed $2.5 \% \mathrm{~N}, 0.87 \% \mathrm{P}, 1.5 \% \mathrm{~K}, 10 \%$ total solids, $58.2 \%$ O.M., $7.5 \mathrm{pH}$ and $90 \%$ moisture content.

\section{1-4.Rhizobium:}

Rhizobium phaseoli was supplied kindly provided by Bio fertilizers Production Unit, Soils, Water Environ. Res. Inst., Agric. Res. Center (ARC), Giza, Egypt.

Table 1. Some physical and chemical properties of the experimental soil

\begin{tabular}{|c|c|c|c|}
\hline Soil characters & Value & Soil characters & Value \\
\hline Coarse sand & 7.43 & Soluble cations (mea $\mathrm{I}^{-1}$ ). & \\
\hline Fine sand & 16.77 & soluble catlons (meq. L ): & \\
\hline Silt & 34.88 & $\mathrm{Ca}^{++}$ & 1.28 \\
\hline Clay & 40.92 & $\mathrm{Mg}^{++}$ & 0.70 \\
\hline \multirow{2}{*}{ Textural class } & \multirow{2}{*}{ Clay loam } & $\mathrm{Na}^{+}$ & 1.70 \\
\hline & & $\mathrm{K}^{+}$ & 0.40 \\
\hline Organic matter content $\%$ & 1.50 & Soluble anions (meq. $\left.\mathrm{L}^{-1-}\right)$ : & \\
\hline E.C $\left(\mathrm{dsm}^{-1}\right)$ & 2.80 & $\mathrm{CO}_{3}^{--}$ & 0.00 \\
\hline T. N\% & 0.40 & $\mathrm{HCO}_{3}{ }^{-}$ & 1.99 \\
\hline T. P\% & 1.20 & $\mathrm{Cl}^{-}$ & 1.42 \\
\hline $\mathrm{pH}(1: 2.5$,soil suspension) & 7.50 & $\mathrm{SO}_{4}^{--}$ & 0.67 \\
\hline
\end{tabular}

Table 2. chemical characteristics of rock phosphate used in study.

\begin{tabular}{|c|c|c|c|}
\hline Chemical character & Value & Chemical character & Value \\
\hline Soluble ions $\left(\mathrm{meqL}^{-1}\right)$ & & \multicolumn{2}{|c|}{ Available macro and micronutrients $\left(\mathrm{mg} \mathrm{kg}^{-1}\right)$} \\
\hline $\mathrm{Ca}^{++}$ & 8.5 & $\mathrm{~N}$ & 32.32 \\
\hline $\mathrm{Mg}^{++}$ & 3.75 & $\mathrm{P}$ & 0.38 \\
\hline $\mathrm{Na}^{+}$ & 16.9 & $\mathrm{~K}$ & 40.5 \\
\hline $\mathrm{K}^{+}$ & 0.85 & $\mathrm{Fe}$ & 0.94 \\
\hline $\mathrm{CO}_{3}=$ & -- & $\mathrm{Zn}$ & 0.90 \\
\hline $\mathrm{H} \mathrm{CO}_{3}^{-}$ & 1.9 & $\mathrm{Mn}$ & 0.38 \\
\hline $\mathrm{Cl}^{-}$ & 25.0 & \multicolumn{2}{|c|}{ Total macro and micronutrients } \\
\hline \multirow{2}{*}{$\mathrm{SO}_{4}=$} & 3.1 & $\mathrm{~N}(\%)$ & 0.17 \\
\hline & & $\mathrm{P}_{2} \mathrm{O}_{5}(\%)$ & 12.0 \\
\hline $\mathrm{pH}(1: 2.5)$ & 7.43 & $\mathrm{~K}_{2} \mathrm{O}(\%)$ & 0.37 \\
\hline ECedS $\mathrm{m}^{-1}$ & 15.99 & $\mathrm{Fe}\left(\mathrm{mg} \mathrm{kg}^{-1}\right)$ & 2.93 \\
\hline $\mathrm{SP} \%$ & 28 & $\mathrm{Zn}\left(\mathrm{mg} \mathrm{kg}^{-1}\right)$ & 106.10 \\
\hline $\operatorname{CEC}\left(\right.$ meq $\left.100 g^{-1}\right)$ & 4.27 & $\operatorname{Mn}\left(\mathrm{mg} \mathrm{kg}^{-1}\right)$ & 285 \\
\hline
\end{tabular}




\section{1-5. Fertilizers used:}

The fertilizers used for snap bean were calcium supper phosphate $\left(15.5 \% \mathrm{P}_{2} \mathrm{O}_{5}\right)$ as a source of $\mathrm{P}$, slurry of biogas as an organic manure, Ammonium sulphate as a source of $\mathrm{N}$ and potassium sulphate as a source of potassium. .

\section{II-Methods:}

A pot experiment was conducted under the green house conditions at Training Center for Recycling of Agricultural Residues (TCRAR) Moshtohor, Kalubia, to evaluate the efficiency of slurry of biogas with rock phosphate and supper phosphate, at recommended dose, on the growth and yield of snap bean. Pots of 30 $\mathrm{cm}$ diameter were filled with $6 \mathrm{Kg}$ soil. Each pot was fertilized with biogas slurry (cattle dung) at rate of $10 \mathrm{~m}^{3}, 5 \mathrm{~m}^{3}$ and $2.5 \mathrm{~m}^{3} / \mathrm{fed}(60 \mathrm{ml}, 30 \mathrm{ml}$ and $15 \mathrm{ml} / \mathrm{pot})$ and with calcium superphosphate (SP)or rock phosphate at recommended dose, $200 \mathrm{Kg} /$ fed $(1.2 \mathrm{gm}$ of superphosphate or $1.5 \mathrm{~g}$ of rock phosphate (RP) /pot. These fertilizers were applied with three doses. Recommended $\mathrm{N}$ and $\mathrm{K}$ at a rate of $60 \mathrm{Kg}$ and $50 \mathrm{Kg}$ / fed, respectively according to Ministry of Agriculture, were applied to all treatments, 200 $\mathrm{Kg} /$ fed of super phosphate was used for the control. Five seeds were sown in the pot at the depth $6 \mathrm{~cm}$. The experiment was arranged in complete randomized design with 4replicates.

\section{Experiment treatments:}

The experiment included 7 treatments for each snap bean variety used

1) $10 \mathrm{~m}^{3}$ biogas slurry $+30 \mathrm{Kg} \mathrm{P}_{2} \mathrm{O}_{5} /$ fed as rock phosphate.

2) $5 \mathrm{~m}^{3}$ biogas slurry $+30 \mathrm{Kg} \mathrm{P}_{2} \mathrm{O}_{5} /$ fed as rock phosphate.

3) $2.5 \mathrm{~m}^{3}$ biogas slurry $+30 \mathrm{Kg}_{2} \mathrm{O}_{5} /$ fed as rock phosphate.

4) $10 \mathrm{~m}^{3}$ biogas slurry $+30 \mathrm{Kg} \mathrm{P}_{2} \mathrm{O}_{5} /$ fed as calcium super phosphate.

5) $5 \mathrm{~m}^{3}$ biogas slurry $+30 \mathrm{Kg} \mathrm{P}_{2} \mathrm{O}_{5} /$ fed as calcium super phosphate.

6) $2.5 \mathrm{~m}^{3}$ biogas slurry $+30 \mathrm{Kg} \mathrm{P}_{2} \mathrm{O}_{5} /$ fed as calcium super phosphate. 1)

7) Control (recommended dose of N, P and K of ministry of agriculture).

\section{Chemical analysis of soil, biogas slurry and rock phosphate:}

Chemical analysis for the soil samples (Table 1) were done as described by Jackson (1973). Chemical analysis of the rock phosphate (Table 2) and biogas slurry was estimated according to Black et al., (1982). $\mathrm{Fe}, \mathrm{Mn}, \mathrm{Cu}$ and $\mathrm{Zn}$ were determined by using
Atomic Absorption (model GBC 932), according to(Cottenieet al., 1961).

Growth and yield parameters:

Random samples of ten plants from each replicates were chosen after 45 days of sowing then some plant growth parameters were estimated, plant height $(\mathrm{cm})$, No. of leaves, Plant dry wt. (g) and No. of branches/ plant. After 60 days (the end of experiment), Pods weight /plant $(\mathrm{g})$, Pod length $(\mathrm{cm})$ and Pod diameter (cm) were estimated.

\section{Chemical analysis of Plant:}

- Total nitrogen in the plant samples was determined using the method of microkjeldahel described by Jackson (1973).

- Total phosphorus and available phosphorus determined according to ApHA, (1989).

- $\quad$ Zn and Fe were determined in plant as described by Jackson (1973).

\section{Microbiological analysis:}

After 45 days, nitrogenase enzyme $\left(\mathrm{N}_{2}\right.$-ase) activity of rhizosphere soil was assayed by the acetylene reduction assay (Hardy et al., 1973).Dehydrogenase (DHA) enzyme activity of rhizosphere soil was determined by the method described by Thalman (1967). Total bacteria were estimated in the rhizosphere by plate count method (Allan, 1959).

\section{Statistical analysis:}

The obtained data were subjected to the proper statistical analysis for the complete randomized block design according to Snedecor and Cochran (1980).Least significant difference (L.S.D.) at 5\% level of significance was used for treatment means comparison. All statistical analysis was performed using analysis of variance technique by means of (M STAT) computer software package.

\section{Results and Discussion}

Vegetative growth and yield and its components:

Data in Table (3) showed the response of snap bean vegetative growth and yield components to biogas slurry (BS) 10,5 and $2.5 \mathrm{~m}^{3}$ /fed with rock phosphate (RP) or super phosphate (SP) at $30 \mathrm{Kg}$ of $\mathrm{P}_{2} \mathrm{O}_{5} /$ fed. Vegetative growth i.e., plant height, No of leaves, plant dry weight and No of branches / plant for two used varieties resulted in significant differences as compared to the control. The highest values of plant height, plant dry weight and No of branches / plant were obtained by $2.5 \mathrm{~m}^{3}$ Bio slurry $+30 \mathrm{Kg} \mathrm{P}_{2} \mathrm{O}_{5} /$ fed as rock phosphate for Xera cultivar while the highest No. of leaves /plant for Xera cultivar (19.3) was obtained using $5 \mathrm{~m}^{3}$ biogas slurry + rock phosphate. 
Table 3. Effect of biogas slurry with rock phosphate and super phosphate on vegetative growth and yield of snap bean

\begin{tabular}{|c|c|c|c|c|c|c|c|c|c|}
\hline \multicolumn{3}{|c|}{ Treatments } & $\begin{array}{c}\text { Plant } \\
\text { height } \\
(\mathrm{cm})\end{array}$ & $\begin{array}{l}\text { No. of } \\
\text { leaves }\end{array}$ & $\begin{array}{c}\text { Plant } \\
\text { dry wt. (g) }\end{array}$ & $\begin{array}{c}\text { No. of } \\
\text { branches/ } \\
\text { plant }\end{array}$ & $\begin{array}{c}\text { Pods } \\
\text { wt./plant } \\
(\mathrm{g})\end{array}$ & $\begin{array}{c}\text { Pod } \\
\text { length } \\
(\mathrm{cm})\end{array}$ & $\begin{array}{c}\text { Pod } \\
\text { diameter } \\
(\mathrm{cm})\end{array}$ \\
\hline \multirow{8}{*}{$\frac{\sqrt[\pi]{0}}{x}$} & $10 \mathrm{~m}^{3} \mathrm{BS}$ & \multirow{3}{*}{$\begin{array}{c}30 \mathrm{Kg} \mathrm{P}_{2} \mathrm{O}_{5} / \mathrm{fed} \\
\text { as RP }\end{array}$} & $22.0 \mathrm{bc}$ & $16.7 \mathrm{~b}$ & $2.10 \mathrm{c}$ & $4.1 \mathrm{bc}$ & $7.50 b^{*}$ & $10.2 \mathrm{abc}$ & 0.55 \\
\hline & $5 \mathrm{~m}^{3} \mathrm{BS}$ & & $25.7 \mathrm{ab}$ & $19.3 \mathrm{a}$ & $2.40 \mathrm{bc}$ & $4.6 \mathrm{~b}$ & $7.00 \mathrm{c}$ & $9.9 \mathrm{bc}$ & 0.63 \\
\hline & $2.5 \mathrm{~m}^{3} \mathrm{BS}$ & & $27.3 \mathrm{a}$ & $16.0 \mathrm{~b}$ & $2.95 \mathrm{a}$ & $5.8 \mathrm{a}$ & $9.15 \mathrm{a}$ & $11.9 \mathrm{a}$ & 0.64 \\
\hline & $10 \mathrm{~m}^{3} \mathrm{BS}$ & \multirow{3}{*}{$\begin{array}{c}30 \mathrm{kG} \mathrm{P}_{2} \mathrm{O}_{5} / \mathrm{fed} \\
\text { as SP }\end{array}$} & $29.0 \mathrm{a}$ & $12.3 \mathrm{bc}$ & $2.75 \mathrm{ab}$ & $5.5 \mathrm{a}$ & $4.90 \mathrm{e}$ & $11.2 \mathrm{abc}$ & 0.72 \\
\hline & $5 \mathrm{~m}^{3} \mathrm{BS}$ & & $25.0 \mathrm{ab}$ & $14.7 \mathrm{bc}$ & $2.30 \mathrm{c}$ & $4.4 \mathrm{~b}$ & $6.54 \mathrm{c}$ & $11.4 \mathrm{ab}$ & 0.68 \\
\hline & $2.5 \mathrm{~m}^{3} \mathrm{BS}$ & & $25.3 \mathrm{ab}$ & $9.3 \mathrm{~d}$ & $1.50 \mathrm{~d}$ & $3.6 \mathrm{c}$ & $6.65 \mathrm{c}$ & $11.0 \mathrm{abc}$ & 0.52 \\
\hline & Control & NPK & $19.7 \mathrm{c}$ & $14.0 \mathrm{bc}$ & $1.70 \mathrm{~d}$ & $3.7 \mathrm{c}$ & $5.55 \mathrm{~d}$ & $9.5 \mathrm{c}$ & 0.50 \\
\hline & \multicolumn{2}{|c|}{$\operatorname{LSD}(0.05)$} & 3.52 & 2.62 & 0.33 & 0.43 & 0.48 & 1.22 & N.S. \\
\hline \multirow{8}{*}{ : } & $10 \mathrm{~m}^{3} \mathrm{BS}$ & \multirow{3}{*}{$\begin{array}{c}30 \mathrm{Kg} \mathrm{P}_{2} \mathrm{O}_{5} / \mathrm{fed} \\
\text { as RP }\end{array}$} & $18.7 \mathrm{~d}$ & $11.7 \mathrm{c}$ & $1.80 \mathrm{~d}$ & $4.80 \mathrm{~b}$ & $3.40 \mathrm{c}$ & 10.0 & 0.54 \\
\hline & $5 \mathrm{~m}^{3} \mathrm{BS}$ & & $19.3 \mathrm{~d}$ & $14.3 \mathrm{~b}$ & $2.10 \mathrm{c}$ & $4.90 \mathrm{~b}$ & $6.40 \mathrm{a}$ & 10.4 & 0.55 \\
\hline & $2.5 \mathrm{~m}^{3} \mathrm{BS}$ & & $24.0 \mathrm{c}$ & $17.0 \mathrm{a}$ & $2.45 \mathrm{~b}$ & $5.65 \mathrm{a}$ & $3.80 \mathrm{c}$ & 12.2 & 0.54 \\
\hline & $10 \mathrm{~m}^{3} \mathrm{BS}$ & \multirow{3}{*}{$\begin{array}{c}30 \mathrm{~kg} \mathrm{P}_{2} \mathrm{O}_{5} / \mathrm{fed} \\
\text { as SP }\end{array}$} & $32.0 \mathrm{a}$ & $17.3 \mathrm{a}$ & $2.75 \mathrm{a}$ & $5.70 \mathrm{a}$ & $4.30 \mathrm{~b}$ & 10.9 & 0.60 \\
\hline & $5 \mathrm{~m}^{3} \mathrm{BS}$ & & $24.0 \mathrm{c}$ & $13.0 \mathrm{bc}$ & $2.48 \mathrm{~b}$ & $5.40 \mathrm{ab}$ & $4.50 \mathrm{~b}$ & 11.7 & 0.64 \\
\hline & $2.5 \mathrm{~m}^{3} \mathrm{BS}$ & & $28.0 \mathrm{~b}$ & $13.7 \mathrm{~b}$ & $2.05 \mathrm{c}$ & $4.90 \mathrm{~b}$ & $2.13 \mathrm{~d}$ & 11.0 & 0.63 \\
\hline & Control & NPK & $18.7 \mathrm{~d}$ & $13.0 \mathrm{bc}$ & $2.20 \mathrm{c}$ & $5.05 \mathrm{ab}$ & $2.17 \mathrm{~d}$ & 10.1 & 0.52 \\
\hline & \multicolumn{2}{|c|}{ LSD $(0.05)$} & 1.04 & 1.19 & 0.34 & 0.49 & 0.44 & $\mathrm{Ns}$ & $\mathrm{Ns}$ \\
\hline
\end{tabular}

RP: Rock phosphate

*Values have the same letter are not significantly different.

For Pulista cultivar, all vegetative growth parameters were obtained their maximum values by $10 \mathrm{~m}^{3} \mathrm{BS}+30 \mathrm{Kg} \mathrm{P}_{2} \mathrm{O}_{5} /$ fed as SP, where the highest No. of leaves /plant were17.3 and 17.0 obtained by $10 \mathrm{~m}^{3} \mathrm{BS}+\mathrm{SP}$ and using $2.5 \mathrm{~m}^{3}$ of biogas slurry + rock phosphate, respectively. Most of the lowest vegetative growth parameters for two used varieties were obtained by the control (full dose of NPK).

With respect to yield and its components, results indicated that both of Pods weight/plant and Pod length of Xera cultivar significantly increased by applying biogas slurry and used different phosphate forms. The highest values of Pods weight/plant and Pod length were $9.15 \mathrm{~g}$ and $11.9 \mathrm{~cm}$, respectively by using $2.5 \mathrm{~m}^{3} \mathrm{BS}+$ rock phosphate, while Pod diameter insignificantly increased over control. The Pods weight/plant of Paulista variety significantly increased when snap bean received $5 \mathrm{~m}^{3} \mathrm{BS}+$ rock phosphate which presented $6.4 \mathrm{~g}$ followed by $4.5 \mathrm{~g}$ by applying $5 \mathrm{~m}^{3} \mathrm{BS}+\mathrm{SP}$. Both of Pod length and Pod diameter insignificantly increased in this variety as a result of using bio slurry and different forms of phosphate fertilizers used in this study. The control treatment caused the minimum values of yield and its components under this study..Sajjad and Shad, 2014 improved that combination of organic and inorganic fertilizers have produced higher yields of wheat. Also, Yield responses of vegetable crops to bio-slurry manure application have been reported in different crops including okra (Shahbaz, 2011), maize and cabbage (Karki, 2001). Krishna, 2001 declared that vegetable crops produced with bio-slurry have better quality as compared to those produced with chemical fertilizer. Gurung (1998) stated that the bio slurry contains nitrogen, phosphor and potassium as well as zinc, iron, manganese and copper, the last of which has become a limited factor in many soils. So, it can be used to build healthy fertile soil for crop production. Also, Sterrett et al., 1988 showed that the addition of organic matter improved the physical, chemical and biological properties of soils and in turn improved the ability of the plant to absorb nutrients which led to increasing in crop production. Jeptoo et al., 2013 emphasize the effect of bio-slurry in carrot when they reported that higher plant heights and leaf numbers obtained could also be attributed to better levels of major nutrients ( $\mathrm{N}, \mathrm{P}$, and $\mathrm{K}$ ) in the bio-slurry manure, as reflected by higher nutrient levels in the growing medium. They added that these findings could be attributed to improved nutrient availability and better soil structure that could have favored shoot and root growth. Garg et al., (2005) reported that wheat grain yield increased with the application of biogas slurry generated from cattle dung, which was attributed to the lower bulk density of soil, increased hydraulic conductivity, and greater moisture retention. Consequently, the improved status of nutrients through amendment of the physical properties of soil contributed to the higher yield of wheat

\section{Leaves chemical composition of snap bean:}

Data presented in Table (4) show the values of NPK $\%$ and content of Fe, Mn, Zn and cu in snap bean leaves as affected by biogas slurry (BS) 10, 5 and 2.5 $\mathrm{m}^{3} /$ fed with rock phosphate (RP) or super phosphate (SP) at $30 \mathrm{Kg}$ of $\mathrm{P}_{2} \mathrm{O}_{5} /$ fed. Results revealed that these factors led to significant increases in these parameters. Regarding macronutrients \%, using of rock phosphate $\left(30 \mathrm{Kg} \mathrm{P}_{2} \mathrm{O}_{5} / \mathrm{fed}\right)$ caused maximum increases in total $\mathrm{N}, \mathrm{P}$ and $\mathrm{K} \%$ in leaves of Xera cultivar when RP was 
applied along with $10 \mathrm{~m}^{3} \mathrm{BS}$ which recorded 4.7, 0.258 and $2.9 \%$, respectively. The highest values of $\mathrm{N}$ and $\mathrm{K} \%$ (3.5 and $2.88 \%$, respectively) in leaves of Pulista cultivar were obtained by using $10 \mathrm{~m}^{3} \mathrm{BS}+\mathrm{RP}$ while the maximum $\mathrm{P} \%(0.330 \%)$ was obtained by $10 \mathrm{~m}^{3} \mathrm{BS}$ + SP. The lowest values of these macronutrients under this study for two cultivars were caused by using the recommended dose of NPK fertilizer (control).

Table 4. Effect of biogas slurry with rock phosphate and super phosphate on leaves chemical composition of snap bean

\begin{tabular}{|c|c|c|c|c|c|c|c|c|c|}
\hline \multirow{2}{*}{\multicolumn{3}{|c|}{ Treatments }} & T.N & T.P & T.K & $\mathrm{Fe}$ & $\mathrm{Mn}$ & $\mathrm{Zn}$ & $\mathrm{Cu}$ \\
\hline & & & & $\%$ & & \multicolumn{4}{|c|}{ Ppm } \\
\hline \multirow{7}{*}{$\underset{\vec{x}}{x}$} & $10 \mathrm{~m}^{3} \mathrm{BS}$ & \multirow{3}{*}{$\begin{array}{c}30 \mathrm{Kg} \mathrm{P}_{2} \mathrm{O}_{5} / \mathrm{fed} \\
\text { as RP }\end{array}$} & $4.700 \mathrm{a}$ & $0.258 \mathrm{a}$ & $2.90 \mathrm{a}$ & $390.0 \mathrm{a}$ & $53.89 a$ & $36.89 \mathrm{~b}$ & $9.89 \mathrm{ab}$ \\
\hline & $5 \mathrm{~m}^{3} \mathrm{BS}$ & & $4.330 \mathrm{a}$ & $0.257 \mathrm{a}$ & $2.02 \mathrm{c}$ & $242.4 \mathrm{~b}$ & $50.33 a$ & $35.00 \mathrm{bc}$ & $10.67 \mathrm{a}$ \\
\hline & $2.5 \mathrm{~m}^{3} \mathrm{BS}$ & & $4.000 \mathrm{~b}$ & $0.240 \mathrm{ab}$ & $2.14 \mathrm{c}$ & $295.0 \mathrm{~b}$ & $48.14 \mathrm{ab}$ & $30.70 \mathrm{c}$ & $8.07 \mathrm{c}$ \\
\hline & $10 \mathrm{~m}^{3} \mathrm{BS}$ & \multirow{3}{*}{$\begin{array}{c}30 \mathrm{kG} \mathrm{P}_{2 \mathrm{j}} \mathrm{O}_{5} / \mathrm{fed} \\
\text { as SP }\end{array}$} & $3.540 \mathrm{c}$ & $0.197 \mathrm{c}$ & $2.83 \mathrm{a}$ & $284.2 \mathrm{~b}$ & $55.94 a$ & $39.40 \mathrm{~b}$ & $9.20 \mathrm{~b}$ \\
\hline & $5 \mathrm{~m}^{3} \mathrm{BS}$ & & $3.920 \mathrm{~b}$ & $0.210 \mathrm{c}$ & $2.45 \mathrm{~b}$ & $146.3 \mathrm{c}$ & $54.77 \mathrm{a}$ & $38.56 b$ & $9.25 \mathrm{~b}$ \\
\hline & $2.5 \mathrm{~m}^{3} \mathrm{BS}$ & & $4.490 \mathrm{a}$ & $0.230 \mathrm{~b}$ & $2.60 \mathrm{ab}$ & $253.8 \mathrm{~b}$ & $42.40 \mathrm{~b}$ & $46.12 \mathrm{a}$ & $10.56 \mathrm{a}$ \\
\hline & Control & NPK & $3.490 \mathrm{c}$ & $0.250 \mathrm{ab}$ & $2.75 \mathrm{ab}$ & $237.0 \mathrm{~b}$ & $49.30 \mathrm{ab}$ & $30.27 \mathrm{c}$ & $9.50 \mathrm{ab}$ \\
\hline \multicolumn{3}{|c|}{ LSD $(5 \%)$} & 0.087 & 0.002 & 0.156 & 41.86 & 2.54 & 0.95 & 0.55 \\
\hline \multirow{8}{*}{$\frac{\mathbb{\pi}}{\stackrel{\mathscr{G}}{\Xi}}$} & $10 \mathrm{~m}^{3} \mathrm{BS}$ & \multirow{3}{*}{$\begin{array}{c}30 \mathrm{Kg} \mathrm{P}_{2} \mathrm{O}_{5} / \mathrm{fed} \\
\text { as RP }\end{array}$} & $3.50 \mathrm{a}$ & $0.252 \mathrm{~b}$ & $2.88 \mathrm{a}$ & $277.3 \mathrm{ab}$ & $47.10 \mathrm{~cd}$ & $38.96 \mathrm{ab}$ & $10.14 \mathrm{c}$ \\
\hline & $5 \mathrm{~m}^{3} \mathrm{BS}$ & & $3.18 \mathrm{ab}$ & $0.260 \mathrm{~b}$ & $2.78 \mathrm{ab}$ & $237.0 \mathrm{bc}$ & $46.90 \mathrm{~cd}$ & $35.86 \mathrm{~b}$ & $9.76 \mathrm{c}$ \\
\hline & $2.5 \mathrm{~m}^{3} \mathrm{BS}$ & & $3.44 \mathrm{a}$ & $0.271 \mathrm{~b}$ & $2.65 b c$ & $345.0 \mathrm{a}$ & $54.39 \mathrm{a}$ & $24.50 \mathrm{c}$ & $11.80 \mathrm{~b}$ \\
\hline & $10 \mathrm{~m}^{3} \mathrm{BS}$ & \multirow{3}{*}{$\begin{array}{c}30 \mathrm{~kg} \mathrm{P}_{2} \mathrm{O}_{5} / \mathrm{fed} \\
\text { as SP }\end{array}$} & $2.75 \mathrm{~b}$ & $0.330 \mathrm{a}$ & $2.55 \mathrm{~cd}$ & $300.0 \mathrm{ab}$ & $50.37 \mathrm{bc}$ & $40.50 \mathrm{a}$ & $11.50 \mathrm{~b}$ \\
\hline & $5 \mathrm{~m}^{3} \mathrm{BS}$ & & $3.00 \mathrm{ab}$ & $0.262 \mathrm{~b}$ & $2.40 \mathrm{de}$ & $198.0 \mathrm{c}$ & $43.70 \mathrm{~d}$ & $24.40 \mathrm{c}$ & $13.16 \mathrm{a}$ \\
\hline & $2.5 \mathrm{~m}^{3} \mathrm{BS}$ & & $3.15 \mathrm{ab}$ & $0.250 \mathrm{~b}$ & $2.30 \mathrm{e}$ & $320.0 \mathrm{a}$ & $51.77 \mathrm{ab}$ & $24.02 \mathrm{c}$ & $10.39 \mathrm{c}$ \\
\hline & Control & NPK & $2.73 \mathrm{~b}$ & $0.245 \mathrm{~b}$ & $2.70 \mathrm{abc}$ & $280.0 \mathrm{ab}$ & $48.60 \mathrm{bc}$ & $28.70 \mathrm{c}$ & $8.33 \mathrm{~d}$ \\
\hline & \multicolumn{2}{|c|}{$\operatorname{LSD}(5 \%)$} & 0.095 & .009 & .034 & 50.84 & 1.64 & 1.30 & 0.44 \\
\hline
\end{tabular}

RP: Rock phosphate SP: Super phosphate

*Values have the same letter are not significantly different.

With respect to $\mathrm{Fe}, \mathrm{Mn}, \mathrm{Zn}$ and $\mathrm{Cu}$ in leaves, data indicated that different $\mathrm{P}$ source fertilizers with biogas slurry (BS) caused significant increases in these micronutrients. For Xera cultivar, Fe content in leaves reached to the maximum contents by $10 \mathrm{~m}^{3} \mathrm{BS}+\mathrm{RP}$. Both of $\mathrm{Mn}$ and $\mathrm{Cu}$ were responded to $\mathrm{RP}$ or to SP where Mn content represented the highest value, 55.94 ppm by using $10 \mathrm{~m}^{3} \mathrm{BS}+\mathrm{SP}$ and represented 53.89 ppm by $10 \mathrm{~m}^{3} \mathrm{BS}+\mathrm{RP}$ without significant differences. Also, $\mathrm{Cu}$ content in leaves recorded 10.67 and 10.56 ppm when seeds received $5 \mathrm{~m}^{3} \mathrm{BS}+\mathrm{RP}$ and $2.5 \mathrm{~m}^{3} \mathrm{BS}$ $+\mathrm{SP}$, respectively. $\mathrm{Zn}$ content represented the maximum value, $46.12 \mathrm{ppm}$ by $2.5 \mathrm{~m}^{3} \mathrm{BS}+\mathrm{SP}$ followed by $39.40 \mathrm{ppm}$ by applying $10 \mathrm{~m}^{3} \mathrm{BS}+\mathrm{SP}$.

Regarding Pulista cultivar, using SP led to significant increase in $\mathrm{Zn}$ and $\mathrm{Cu}$ which recorded 40.50 and $13.16 \mathrm{ppm}$ by $10 \mathrm{~m}^{3} \mathrm{BS}$ and $5 \mathrm{~m}^{3} \mathrm{BS}$, respectively. Applying $2.5 \mathrm{~m}^{3} \mathrm{BS}$ with RP gave the highest content of $\mathrm{Fe}, 345.0 \mathrm{ppm}$ followed by 320.0 ppm by using $2.5 \mathrm{~m}^{3} \mathrm{BS}+\mathrm{SP}$. The maximum $\mathrm{Mn}$ content was obtained by $2.5 \mathrm{~m}^{3} \mathrm{BS}+\mathrm{RP}$.

The increase of nutrient uptake by snap bean in treatment fertilized by organic manure can be attributed to their role in plant growth as a source of all necessary macro and micronutrients in available forms. These results are in accordance with those reported by Abou-zeid and Bakry (2011).

\section{Pod chemical composition of snap bean:}

The influence of biogas slurry and various sources of phosphate fertilizers on chemical composition of snap bean pod is shown in Table (5). Data showed significant increases in $\mathrm{N}, \mathrm{P}, \mathrm{K} \%$, total protein and some micronutrients, $\mathrm{Fe}, \mathrm{Mn}, \mathrm{Zn}$ and $\mathrm{Cu}$ in pod as a result of the above mentioned treatments for Xera cultivar. The maximum values of $\mathrm{N}, \mathrm{K}$ and total protein $\%$ were obtained by using calcium superphosphate (SP), where applying $10 \mathrm{~m}^{3}$ of bio slurry (BS) gave $3.98,3.80$ and $24.88 \%$ of N, K and total protein \% respectively. Using rock phosphate (RP) with $10 \mathrm{~m}^{3}$ bioslurry led to the highest value $(0.479 \%)$ of $\mathrm{P} \%$. Regarding some micronutrients, results from the Table showed that $\mathrm{Fe}$ and $\mathrm{Zn}$ reached the maximum values, 444 and $50.7 \mathrm{ppm}$ when snap bean fertilized with $\mathrm{RP}+10 \mathrm{~m}^{3} .102 .9$ and $101.75 \mathrm{ppm}$ were the highest values of Mn when applying $10 \mathrm{~m}^{3}$ of $\mathrm{BS}$ with RP and SP, respectively. $\mathrm{Cu}$ was more effective with SP where it gave 19.6 and $17.5 \mathrm{ppm}$ with using $10 \mathrm{~m}^{3}$ and $2.5 \mathrm{~m}^{3}$ bioslurry, respectively.

For Paulista cultivar, data in Table (5) indicated that $\mathrm{N}, \mathrm{P}$, total protein, $\mathrm{Fe}$ and $\mathrm{Mn}$ significantly increased over control as a result of BS and RP or SP. In more details, both of $\mathrm{N} \%$ and total protein gave the highest percentage, 4.23 and $36.44 \%$ by using $10 \mathrm{~m}^{3}$ and RP. $10 \mathrm{~m}^{3}$ of biogas slurry with SP led to the maximum value of $\mathrm{P} \%(0.553 \%)$ followed by $0.547 \%$ by applying $5 \mathrm{~m}^{3}$ of $\mathrm{BS}+\mathrm{SP}$.

With regard to $\mathrm{Fe}$ and $\mathrm{Mn}$ concentration (ppm), results revealed that $10 \mathrm{~m}^{3}$ of $\mathrm{BS}+\mathrm{RP}$ led to the maximum percentage of $\mathrm{Fe}$ while, the same rate of BS + SP gave the highest Mn (97.4 ppm). K\%, Zn and $\mathrm{Cu}$ ppm insignificantly increased by using BS and RP or SP. 
Table 5. Effect of biogas slurry with rock phosphate and super phosphate on pod chemical composition of snap bean

\begin{tabular}{|c|c|c|c|c|c|c|c|c|c|c|}
\hline \multirow{2}{*}{\multicolumn{3}{|c|}{ Treatments }} & T.N & T.P & T.K & T.protein & $\mathrm{Fe}$ & $\mathrm{Mn}$ & $\mathrm{Zn}$ & $\mathrm{Cu}$ \\
\hline & & & \multicolumn{4}{|c|}{$\%$} & \multicolumn{4}{|c|}{ ppm } \\
\hline \multirow{7}{*}{$\frac{\pi}{\overrightarrow{0}}$} & $10 \mathrm{~m}^{3} \mathrm{BS}$ & \multirow{3}{*}{$\begin{array}{c}30 \mathrm{Kg} \\
\mathrm{P}_{2} \mathrm{O}_{5} / \text { fed } \\
\text { as RP }\end{array}$} & $3.75 \mathrm{ab}$ & $0.479 \mathrm{a}$ & $2.59 \mathrm{c}$ & $23.44 \mathrm{bc}$ & $444 \mathrm{a}$ & $102.90 \mathrm{a}$ & $50.70 \mathrm{a}$ & $15.7 \mathrm{ab}$ \\
\hline & $5 \mathrm{~m}^{3} \mathrm{BS}$ & & $3.01 \mathrm{c}$ & $0.458 \mathrm{a}$ & 2.89 bc & $18.80 \mathrm{e}$ & $424 \mathrm{a}$ & $75.49 \mathrm{c}$ & $41.24 \mathrm{ab}$ & $8.76 \mathrm{c}$ \\
\hline & $2.5 \mathrm{~m}^{3} \mathrm{BS}$ & & $3.87 \mathrm{ab}$ & $0.474 \mathrm{a}$ & $2.03 \mathrm{~d}$ & $24.19 \mathrm{ab}$ & $211 d$ & $49.90 \mathrm{~d}$ & $29.47 b$ & $13.39 \mathrm{abc}$ \\
\hline & $10 \mathrm{~m}^{3} \mathrm{BS}$ & \multirow{3}{*}{$\begin{array}{c}30 \mathrm{kG} \\
\mathrm{P}_{2} \mathrm{O}_{5} / \mathrm{fed} \\
\text { as SP }\end{array}$} & $3.98 \mathrm{a}$ & $0.320 \mathrm{c}$ & $3.80 \mathrm{a}$ & $24.88 \mathrm{a}$ & $269 c$ & $101.75 \mathrm{a}$ & $24.50 \mathrm{~b}$ & $19.60 \mathrm{a}$ \\
\hline & $5 \mathrm{~m}^{3} \mathrm{BS}$ & & $3.60 \mathrm{ab}$ & $0.382 \mathrm{~b}$ & $3.55 \mathrm{a}$ & $22.50 \mathrm{c}$ & $346 \mathrm{~b}$ & $90.75 \mathrm{ab}$ & $23.00 \mathrm{~b}$ & $14.75 \mathrm{abc}$ \\
\hline & $2.5 \mathrm{~m}^{3} \mathrm{BS}$ & & $2.75 \mathrm{c}$ & $0.391 \mathrm{~b}$ & $2.52 \mathrm{c}$ & $19 \mathrm{f}$ & $137 \mathrm{e}$ & $100.20 \mathrm{a}$ & $28.40 \mathrm{~b}$ & $17.50 \mathrm{a}$ \\
\hline & Control & NPK & $3.40 \mathrm{~b}$ & $0.388 \mathrm{~b}$ & $3.02 \mathrm{~b}$ & $21.00 \mathrm{~d}$ & $360 \mathrm{~b}$ & $82.70 \mathrm{bc}$ & $42.00 \mathrm{ab}$ & $10.15 \mathrm{bc}$ \\
\hline \multicolumn{3}{|c|}{ LSD $(5 \%)$} & 0.38 & 0.03 & 0.30 & 1.01 & 55.70 & 11.58 & 14.93 & 4.61 \\
\hline \multirow{8}{*}{$\frac{\sqrt[\pi]{\mathscr{m}}}{\stackrel{\Xi}{\Xi}}$} & $10 \mathrm{~m}^{3} \mathrm{BS}$ & \multirow{3}{*}{$\begin{array}{c}30 \mathrm{Kg} \\
\mathrm{P}_{2} \mathrm{O}_{5} / \mathrm{fed} \\
\text { as RP }\end{array}$} & $4.23 \mathrm{a}$ & $0.444 \mathrm{ab}$ & 3.40 & $36.44 \mathrm{a}$ & $473 \mathrm{a}$ & $74.00 \mathrm{c}$ & 37.00 & 15.57 \\
\hline & $5 \mathrm{~m}^{3} \mathrm{BS}$ & & $3.85 \mathrm{ab}$ & $0.367 \mathrm{~b}$ & 2.80 & $24.06 \mathrm{~b}$ & $328 \mathrm{c}$ & $41.30 \mathrm{e}$ & 38.50 & 12.25 \\
\hline & $2.5 \mathrm{~m}^{3} \mathrm{BS}$ & & $3.90 \mathrm{ab}$ & $0.390 \mathrm{~b}$ & 3.08 & $24.38 \mathrm{~b}$ & $459 \mathrm{a}$ & $85.80 \mathrm{~b}$ & 39.17 & 12.50 \\
\hline & $10 \mathrm{~m}^{3} \mathrm{BS}$ & \multirow{3}{*}{$\begin{array}{c}30 \mathrm{kG} \\
\mathrm{P}_{2} \mathrm{O}_{5} / \text { fed } \\
\text { as SP }\end{array}$} & $2.90 \mathrm{~b}$ & $0.553 \mathrm{a}$ & 3.38 & $18.13 \mathrm{c}$ & $363 \mathrm{bc}$ & $97.40 \mathrm{a}$ & 42.17 & 11.90 \\
\hline & $5 \mathrm{~m}^{3} \mathrm{BS}$ & & $4.00 \mathrm{a}$ & $0.547 \mathrm{a}$ & 3.24 & $25.00 \mathrm{bc}$ & $240 \mathrm{~d}$ & $52.27 \mathrm{de}$ & 42.80 & 8.90 \\
\hline & $2.5 \mathrm{~m}^{3} \mathrm{BS}$ & & $3.38 \mathrm{ab}$ & $0.400 \mathrm{~b}$ & 2.77 & $21.13 \mathrm{~b}$ & $193 \mathrm{~d}$ & $42.50 \mathrm{e}$ & 47.60 & 11.16 \\
\hline & Control & NPK & $3.50 \mathrm{ab}$ & $0.464 \mathrm{ab}$ & 2.90 & 22.00 & $424 \mathrm{ab}$ & $61.00 \mathrm{~d}$ & 40.50 & 12.68 \\
\hline & \multicolumn{2}{|c|}{$\operatorname{LSD}(5 \%)$} & 0.72 & 0.08 & N.S & 3.10 & 61.17 & 9.27 & ns. & Ns \\
\hline
\end{tabular}

RP: Rock phosphate SP: Super phosphate

*Values have the same letter are not significantly different.

Somasundaramet al., (2007) reported that increased soluble protein content of maize, sunflower, and green gram (Vignaradiata L.) was estimated with biogas slurry. These increases as a result of applying biogas slurry, which are in accordance with those obtained by Mahdy, 2003 who stated that organic manure attains more pronounced contents of macro$(\mathrm{N}, \mathrm{P}$ and $\mathrm{K})$ and micronutrients $(\mathrm{Fe}, \mathrm{Mn}, \mathrm{Zn}$ and $\mathrm{Cu}$ ), which was consequently reflected on plant growth and yield. Also Fentaw (2010) stated that Compost and bio slurry improves the physical, chemical and biological quality of soil besides providing both macro and micro nutrients to crops. The improvement in qualities include improvement in soil structure, water holding capacity, electrical conductivity, bulk density, lesser soil erosion, preventing the leaching of nutrients and provide nutrients to soil micro flora.

\section{Biological activity and available phosphorus:}

The response of biological activity parameters i. e, dehydrogenase and nitrogenase activity,total count of bacteria, also available phosphorus to biogas slurry (BS) with various sources of phosphorus fertilizers is shown in Table (6). All the previous parameters are significantly increased as a result of using BS and super phosphate (SP) or rock phosphate (RP) for the two used varieties. Data revealed that these biological activity parameters increased concomitantly with the increase of biogas slurry (BS) doses for the two used varieties with SP or RP. Using of RP as a phosphate fertilizer led to more increase of the values in these parameters than SP. Control treatment (the recommended dose of $\mathrm{N}, \mathrm{P}$ and $\mathrm{K}$ ) gave the lowest values of above mentioned parameters. The highest
DHA, total bacteria and $\mathrm{N}_{2}$-ase activity were $201.5 \mu \mathrm{g}$ $\mathrm{TPF} / \mathrm{g}$ rhizosphere soil/day, $17.2 \times 10^{6}$ and 44.5 nmole $\mathrm{C}_{2} \mathrm{H}_{4} / \mathrm{g}$ rhizosphere soil/h of the plants received $10 \mathrm{~m}^{3} \mathrm{BS}+30 \mathrm{~kg} \mathrm{P}_{2} \mathrm{O}_{5} /$ fed as $\mathrm{RP}$ for Xera cultivar, while the corresponding values were 212.8 $\mu \mathrm{g}$ TPF, $28.8 \times 10^{6}$ and 86.2 nmole $_{2} \mathrm{H}_{4}$ for the other variety with the same treatment. These results are in agreement with those by Abou-zeid and Bakry (2011) who reported that the addition of organic manures to the soil encourage proliferation of soil microorganisms which consequently increased the values of dehydrogenase enzyme activity. This may be due to the vital role of organic materials in enriching community of soil microorganisms of the rhizosphere of snap bean.

With respect to available $P$, results indicated that there are significant increases in available $\mathrm{P}$ as a result of BS and SP or RP. The fertilization with SP gave the maximum values of available $P$ for Xera cultivar, which recorded $24.64 \mathrm{ppm}$ by $10 \mathrm{~m}^{3} \mathrm{BS}+\mathrm{SP}$ followed by $23.11 \mathrm{ppm}$ by $5 \mathrm{~m}^{3} \mathrm{BS}+\mathrm{SP}$ then $20.52 \mathrm{ppm}$ with the control while the minimum value, $5.82 \mathrm{ppm}$ was presented by using $2.5 \mathrm{~m}^{3} \mathrm{BS}+\mathrm{SP}$. Regarding Paulista cultivar, $10 \mathrm{~m}^{3} \mathrm{BS}+\mathrm{RP}$ gave the highest value of available P, $34.31 \mathrm{ppm}$ followed by $21.51 \mathrm{ppm}$ and 20.06 ppm by applying $5 \mathrm{~m}^{3} \mathrm{BS}+\mathrm{SP}$ and $2.5 \mathrm{~m}^{3} \mathrm{BS}+$ $\mathrm{SP}$, respectively. Somasundaramet al., (2007) reported that increased nitrogenase activity of maize, sunflower, and green gram (Vignaradiata L.) was estimated with biogas slurry. Hu et al., (2006) added that The different types of organic manure increase the microorganisms, release acids in the root rhizosphere and may help to solubilize $\mathrm{P}$ and to increase $\mathrm{P}$ availability to the plants. 
Table 6. Effect of biogas slurry with rock phosphate or super phosphate on dehydrogenase and nitrogenase activity, total count of bacteria and available phosphor of snap bean soil

\begin{tabular}{|c|c|c|c|c|c|c|c|c|}
\hline \multirow[t]{2}{*}{ Treatments } & 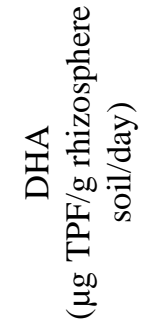 & 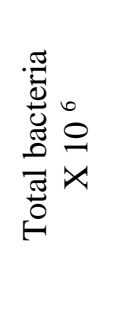 & 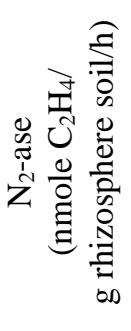 & $\begin{array}{l}0 \\
\frac{0}{0} \\
\frac{\pi}{0} \\
\frac{\pi}{\pi} \\
\frac{\pi}{2}\end{array}$ & 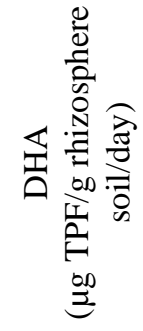 & 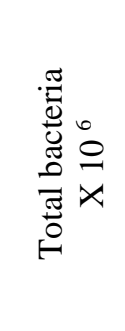 & 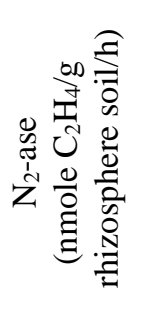 & 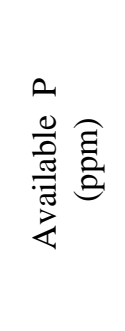 \\
\hline & \multicolumn{4}{|c|}{ Xera } & \multicolumn{4}{|c|}{ Pulista } \\
\hline \multirow{3}{*}{$\begin{array}{c}30 \mathrm{Kg} \mathrm{P}_{2} \mathrm{O}_{5} / \mathrm{fed} \\
\text { as RP }\end{array}$} & $201.5 \mathrm{a}$ & $17.2 \mathrm{a}$ & $44.5 \mathrm{a}$ & $11.43 \mathrm{c}$ & $212.8 \mathrm{a}$ & $\begin{array}{c}28.8 \\
\mathrm{a} \\
\end{array}$ & $86.2 \mathrm{a}$ & $34.69 \mathrm{c}$ \\
\hline & $142.4 \mathrm{bc}$ & $14.5 \mathrm{~b}$ & $21.7 \mathrm{~cd}$ & $9.14 \mathrm{~d}$ & $111.6 \mathrm{c}$ & $25.2 \mathrm{ab}$ & $72.5 \mathrm{a}$ & $10.41 \mathrm{~d}$ \\
\hline & $104.2 \mathrm{~cd}$ & $10.3 \mathrm{c}$ & 15.4 & $9.08 \mathrm{~d}$ & $101.7 \mathrm{~cd}$ & $11.2 \mathrm{c}$ & $51.1 \mathrm{~b}$ & $14.31 \mathrm{a}$ \\
\hline \multirow{3}{*}{$\begin{array}{c}30 \mathrm{~kg} \mathrm{P}_{2} \mathrm{O}_{5} / \mathrm{fed} \\
\text { as SP }\end{array}$} & $172.8 \mathrm{ab}$ & $15.1 \mathrm{~b}$ & $31.3 \mathrm{~b}$ & $24.11 \mathrm{a}$ & $151.4 \mathrm{~b}$ & $21.1 \mathrm{~b}$ & $33.4 \mathrm{c}$ & $21.64 \mathrm{c}$ \\
\hline & $125.6 \mathrm{c}$ & $9.2 \mathrm{~cd}$ & $25.1 \mathrm{c}$ & $23.64 \mathrm{a}$ & $110.8 \mathrm{c}$ & $20.5 \mathrm{~b}$ & $15.9 \mathrm{~d}$ & $20.51 \mathrm{~b}$ \\
\hline & $81.3 \mathrm{~d}$ & $8.1 \mathrm{de}$ & $19.0 \mathrm{de}$ & $5.82 \mathrm{e}$ & $80.0 \mathrm{~d}$ & $9.5 \mathrm{c}$ & $12.4 \mathrm{~d}$ & $16.06 \mathrm{~b}$ \\
\hline Control NPK & $71.2 \mathrm{~d}$ & $7.0 \mathrm{e}$ & $12.2 \mathrm{f}$ & $20.52 \mathrm{~b}$ & $49.2 \mathrm{e}$ & $12.5 \mathrm{c}$ & $18.1 \mathrm{~cd}$ & $15.99 \mathrm{c}$ \\
\hline $\operatorname{LSD}(5 \%)$ & 39.16 & 1.16 & 4.39 & 1.89 & 26.53 & 5.92 & 15.61 & 2.65 \\
\hline
\end{tabular}

\section{Conclusion}

Amending soils with bio-slurry manure enhances the vegetative growth, pods yield of snap bean. This study ensured that the use of rock phosphate with biogas slurry may be recommended as a substitute for super phosphate with biogas slurry in snap bean production.

\section{References}

Abou-Zeid, M. Y. and Bakry, M. A. A.(2011): Integrated effect of Bio-organic manures and mineral Ertilizers on Potato productivity and the fertility Status of a alcareous Soil. Australian Journal of Basic and Applied Sciences, 5(8): 13851399

Adesanwo, O. O.; Adetunji, M. T. and Diatta, S. (2012): Effect of legume incorporation on solubilization of Ogun phosphate rock onslightly acidic soils in SW Nigeria, J. Plant Nutr. Soil Sc., 175, 377-384.

Allen, O. M. (1959). Experiments in soil bacteriology. $1^{\text {st }}$ Ed Burgss publishing Co. Minneapolis, Minnesota. USA.

APHA American Pablic Health Association (1989): Standard methods for the examination of water and west water. Washington, D.C., USA.

Begum, M.; Narayanasamy, G. and Biswas, D. R.: Phosphorus supplying capacity of phosphate rocks as influenced by compaction with water-soluble $\mathrm{P}$ fertilizers, Nutr. Cycl.Agroecosys., 68, 73- 84, 2004.

Black, C.A. D.O.; Evans, L.E.; Ensminger, J.; White, F.E. Clark and Dinaure, R.C.
1982. Methods of Soil Analysis. Part 2 Chemical and microbiology properties, 2nd Ed. Soil Sci., Soc. Of Am. Inc. Publ., Madison, U.S.A. Wisconsin.

Cottenie, A.;Verloo, M.; Velghe,G. and Cameriynck, $R$. (1961): "Chemical analysis of plant and soil".laboratory of analytical and agrochemistry.State Univ., Ghent, Belgium.

Fentaw, E. (2010). Bio-slurry in Ethiopia: what is it and how to use it, Institute for Sustainable Development (ISD) and National Biogas Program Ethiopia Coordination Office. Addis Ababa, Ethiopia.

Garg, R.N.; Pathak, H.; Das, D.K.; and Tomar, R.K. (2005) Use of flyash and biogas slurry for improving wheat yield and physical properties of soil. Environ. Monit. Assess.107, 1-9.

Gurung, B. (1998). Training programme on proper use of slurry for the technical staff of SNV/BSP.A training manual.

Hardy, R.W.F.; Burns, R.C. and Holsten, R.O. (1973).Application of the acetylene - ethylene assay for measurement of nitrogen fixation. Soil Boil. Biochem 5: 47-81.

Hu, X.; Chen, J. and Guo, J. (2006): Two phosphateand potassiumsolubilizing bacteria isolated from Tianmu Mountain, Zhejiang, China, World J. Microb. Biot., 22, 983-990.

Hukkeri, S. B.; Shukla, N. P. and Rajput, R. K. (1977) Effect of levels of soil moisture and nitrogen on the fodder yield of oat on two types of soils. Indian J. Agron., 47: 204-209.

Islam, S. (2006).Use of Bio-slurry as Organic Fertilizer in Bangladesh Agriculture.Prepared for 
International Workshop on the use Bio-slurry for Domestic Biogas Programmes $27^{\text {th }}-28^{\text {th }}$ September, Bangkok, Thailand.

Jackson, M. L. (1973)."Soil Chemical Analysis". Prentice-Hall of India, New Delhi.,India.

Jeptoo, A.; Aguyoh, J. N. and Saidi, M. (2013): Improving carrot yield and quality through the use of bio-slurry manure. Sustainable Agriculture Research; Vol. 2, No. 1: 164-172.

Karki, K. B. (2001). Response to bio-slurry Application on Maize and cabbage in Laliptur District. Final Field Research Report Submitted to Alternative Energy Promotion Centre of Ministry of Science and Technology. October, 2001. Pulchok .Nepal.

Karki, K.B. and Gurung, B. (1996). Evaluation of slurry extension pilot programme. SNV/BSP.

Khan, M. S.; Zaidi, A. and Ahmad, E. (2014): Mechanism of phosphate solubilization and physiological functions of phosphate solubilizing microorganisms, In: Phosphate Solubilizing Microorganisms: Principles and application of microphos technology, edited by: Khan, M. S., Zaidi, A., and Musarrat, J., Springer International Publishing Switzerland, Switzerland, 31- 62, doi:10.1007/978-3-319-08216-5_2,

Krishna, P.G. 2001. Response to bio-slurry application on maize and cabbage in Lalitpur District.Final Report his Majesty's Government of Nepal, Ministry of Science and Technology.Alternative Energy Promotion Centre, Nepal.

Mahdy Hayam, A.A. ( 2003). Effect of some organic conditioners on plant growth and some nutrients uptake of sandy soil under drip irrigation. M. Sc. Thesis, Fac. of Agric. at Moshtohor, Zagazig Univ., Egypt.

Mehta, P.; Walia, A.; Kulshrestha, S.; Chauhan, A., and Shirkot, C.K. (2014): Efficiency of plant growth-promoting P-solubilizing Bacillus circulans $\mathrm{CB} 7$ for enhancement of tomato growth under net house conditions, J. Basic Microb., 53, $1-12$.

Møller, J.; Boldrin, A., Christensen, T. H. (2009): Anaerobic digestion and digestate use: accounting of greenhouses gases and global warming contribution. Waste Manage. Res. 27, 813-824.

Möller, K. (2009): Inner farm nutrient flows between arable land and permanent grassland via the stable in organic cropping systems. Eur. J. Agron. 31, 204-212.

Nishanth, D. and Biswas, D. R.( 2008): Kinetics of phosphorus and potassium release from rock phosphate and waste mica enriched compost and their effect on yield and nutrient uptake by wheat
(Triticumaestivum), Bioresource Technol., 99, 3342-3353,

Panhwar, Q. A.; Radziah, O.; Zaharah, A. R.; Sariah, M. and Razi, I. M.(2011): Role of phosphate solubilizing bacteria on rock phosphate solubility and growth of aerobic rice, J. Environ. Biol., 32, 607-612.

Qureshi, M. A.; Ahmad, Z. A.; Akhtar, N. and Iqbal, A.(2012): Role of phosphate solubilizing bacteria (PSB) in enhancing P-availability and promoting cotton growth, J. Anim. Plant Sci., 22, 204-210.

Sajjad, K. and Shad, K. K. (2014). Integrated use of organic and inorganic fertilizers in wheat and their residual effect on subsequent mung bean, International journal of farming and allied sciences. Kabul, Afghanistan.

Saleem, M. M.; Arshad, M. and Yaseen, M.(2013): Effectiveness of various approaches to use rock phosphate as a potential source of plant available $\mathrm{P}$ for sustainable wheat production, Int. J. Agric. Biol., 15, 223-230.

Shahabz, M. (2011).Potential of bio-slurry and compost at different levels of inorganic nitrogen to improve growth and yield of okra (Hibiscus esculetusL.).Msc.Thesis, University of Agriculture Faisalabad, Pakistan.

Snedecor, G.W. and Cochran,W.G. 1980. Statistical Methods 7th Ed, Iowa State Univ. Press, Iwoa. U.S.A.

Somasundaram, M.; $\quad$ Mohamed, A.; Thirukkumaran, K. ; Chandrasekaran, K. Vaiyapuri, and Sathyamoorthi, K. (2007). "Biochemical changes, nitrogen flux and yield of crops due to organic sources of nutrients under maize based cropping system," Journal of Applied Sciences Research, vol. 3, pp. 1724-1729.

Thalmann, A. (1967). Uber die microbiello aktiviatat undih rbenziehung zu frucht- bartkeits merkmalen einiger Acherboden unter besonderer Beruksi chtigung der Dehydrogenase aktiviatat (TTC. Reduktion ). Biss, Gieben. Ph. D. Thesis, W. Germany.

Thu, L. T. X. (2007). Bio-slurry Utilization in Vietnam.Half Year Country Report.

Weltzein, H. C. (1990) The use of composted materials for leaf disease suppression in field crops. Crop protection in organic and low-input agriculture. BCPC Monographs, 45: 115-120.

Wentzel, S and Joergensen, R. G (2016).Effects of biogas and raw slurries on grass growth and soil microbial indices. J. Plant Nutr. Soil Sci. 179, 215-222.

Zou, K.; Binkley, D. and Doxtadar, K. G.: New methods for estimating gross $\mathrm{P}$ mineralization rates in soils, Plant Soil, 147, 243-250, 1992 


\section{استجابة الفاصوليا لسماد البيوجاز السائل مخلوط مع سمادى صخر الفوسفات أو سوبر الفوسفات

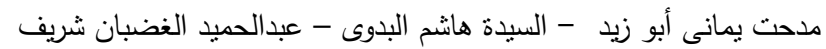

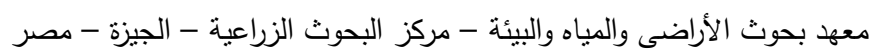

تثتـل هذه الدراسـة تأثير سماد البيوجاز السـائل(BS) تحت ظروف الصـوبة على نمو وانتاج الفاصـوليا والتركيب الكيميائى وبعض انزيمات التربة

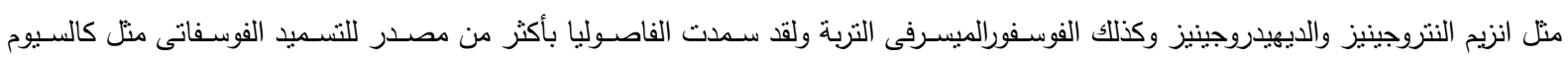

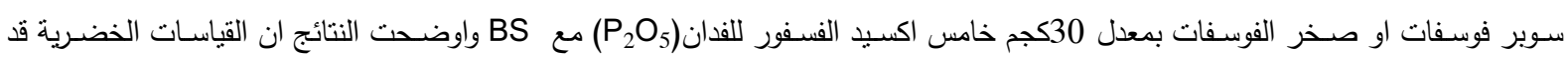

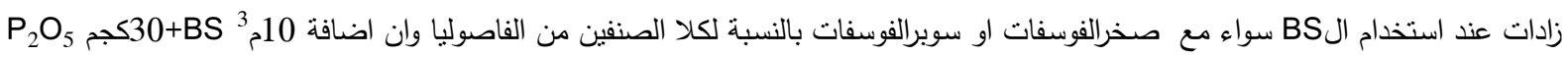

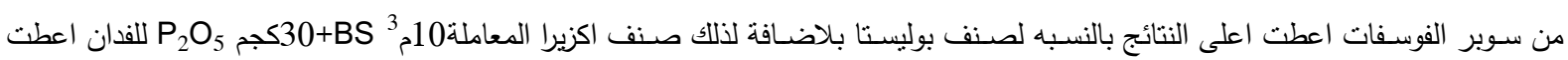

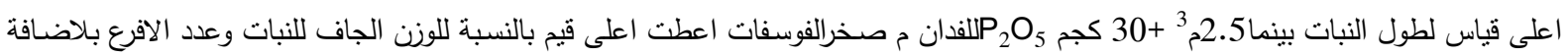

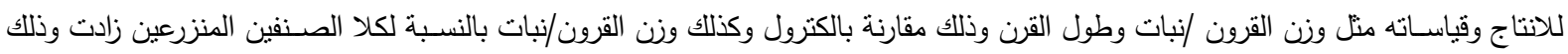

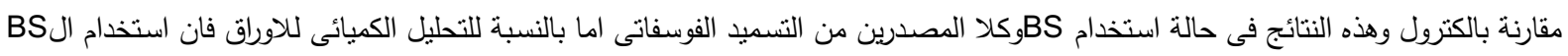

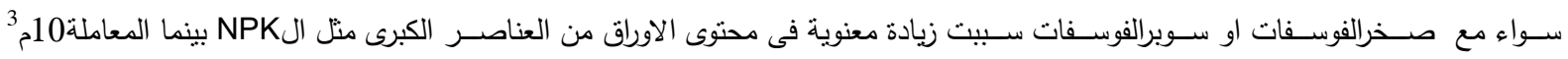

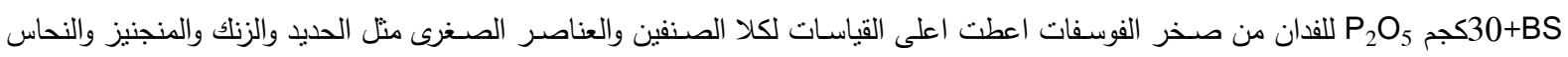

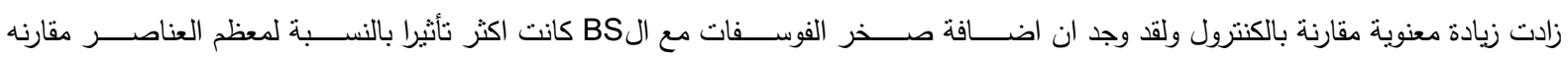
بالسوبرفوسفات + الBS بالنسبة للصنفين المنزرعين اما بالنسبة للتحليل الكيماوى للقرون فان تركيز عنصرى الم, N,K والبروتين الكلى زادت زيادي

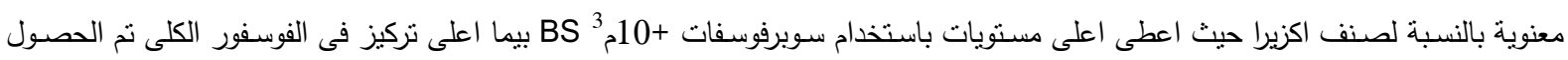

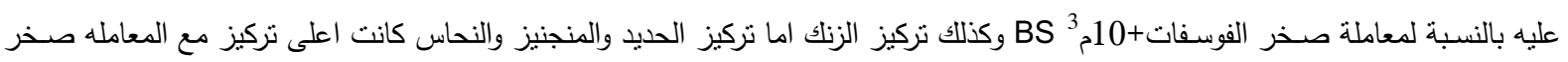

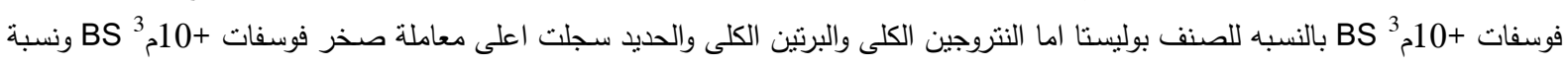

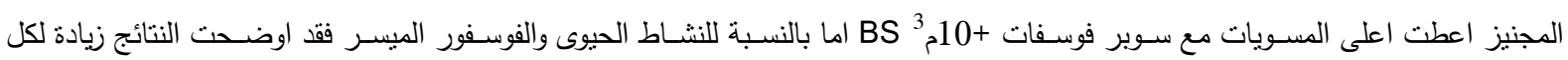

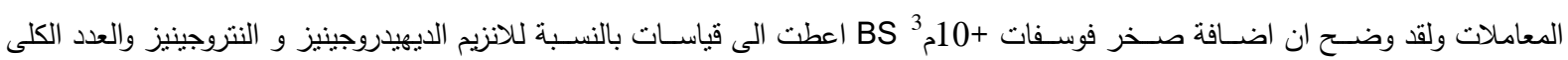

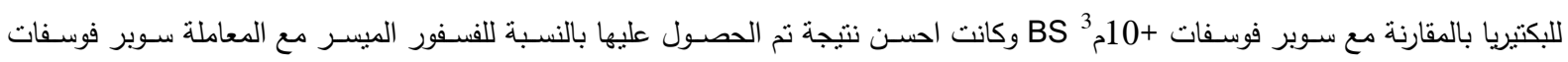

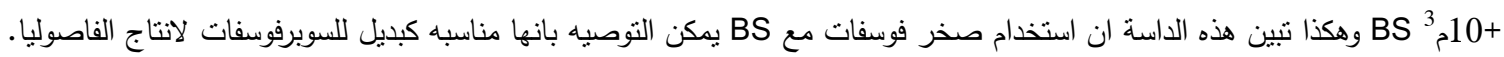

